\title{
連載:世界各国のIT政策
}

\section{第7回 スウェーデン}

\section{兼子利夫 ${ }^{1}$}

著者抄録 : 世界的に1990年代からインターネットとPCが急速に普及し始め, 産業活動はもちろんの こと一般社会にもその活用が広がりつつある。そのひとつのビジネス形態が, 電子商取引である。各 国の政府機関等では，これらの情報技術（Information Technology: IT）を積極的に政策に取り込み， 自国のIT政策として展開している。本稿では, 最初にスウェーデンのIT政策の経緯を述べ, そして, 同国のIT政策の基本である「全国民のための情報社会」の概要について述べる。次に，情報技術ク ラスターの現状について, 最後に, IT産業の一分野としてデジタル・ゲーム産業とIT政策戦略グルー プについて記述する。

キーワード : スウェーデン, 全国民のための情報社会, 情報技術クラスター, デジタル・ゲーム産 業, IT政策戦略グループ

\section{IT Policies of the Major Countries and Economies No. 7 Sweden}

\section{KANEKO Toshio ${ }^{1}$}

Author Abstract: The Internet and PCs have been spreading in the world since the 1990s. The usage of these technologies has been expanding not only in the business field but also in the ordinary society. One of those business styles is Electronic Commerce. Most of the governments of countries and economies are taking these information technologies into their policies and developing them as their own IT policy. This paper, first, takes a general view of the IT policy progress of Sweden, and describes a basic IT policy, "Information Society for All". And next it mentions the IT clusters. Last it describes the digital game industry as one of the IT industries and "IT Policy Strategic Group".

Key words: Sweden, Information Society for All, IT clusters, digital game industry, IT Policy Strategic Group

\section{1. スウェーデンにおけるIT政策の経緯}

本章では, スウェーデンの情報技術（Information Technology: IT）政策の最近の経緯について概観す る。スウェーデンは, 情報技術, 通信, ニューメ ディアで世界をリードしており, 米国をもしのぎ 世界最強の情報技術国と言われている。World Economic Forumが, 2005年3月に「Global Information Technology Report 2004-2005」を発表したが，ス ウェーデンは世界ランキング6位に位置付けられて (る1)。
1994年3月，情報技術委員会が，政府内に創設さ れた。首相を議長とし，「国民の生活を豊かにし， スウェーデンの国際競争力を強化するために, 情 報技術の利用を促進する」ことを目的とした。

1994年8月, 同委員会は, 「情報技術：人間の能 力を飛翔させるもの」と題するレポートをまとめ た。このレポートは情報社会へ向けたスウェーデ ンのビジョンを明らかにし,「教育と研究」,「法 制」,「一般行政」,「保健医療」,「通信ネットワー ク」,「商工業」「情報技術リサーチ」の7つの領域 について提言している。

1 （財）日本情報処理開発協会＼cjkstart調査部（干105-0011東京都港区芝公園3-5-8＼cjkstart機械振興会館内） Tel. 03 (3432) 3467 E-mail: tkaneko@res.jipdec.jp

${ }^{1}$ Research Department, Japan Information Processing Development Corporation (JIPDEC) (Kikai Shinko Kaikan Bldg. 3-5-8 Shibakoen Minato-ku, Tokyo 105-0011) 
1996年3月, 同委員会による提言に基づき, 政府 は議会に情報技術議案を提出した。これはスウェー デンとしての最初の情報技術戦略を定義するもの であり，情報技術の普及と発展のための政策を提 起した。

1996年3月, 運輸通信大臣を議長とする第三期の 情報技術委員会がスタートした。1996年の6月に は, 政府の情報技術議案の結果として, 情報技術 委員会に新しい「枠組み」が提起された。

1998年, 第四期情報技術委員会がスタートした。 同委員会の議長は, 産業雇用通信省が務めること となった。任期は 3 年から 5 年に延長され，より長 期的なべースで活動できるようになった。同委員 会は, 政府と協議して, 年間プログラムを作成す る。政府とは定期的に協議し, 毎年活動レポート を作成する。委員会事務局は, 各分野で活動する 作業グループを助け協力する体制とした。

1996年から1999年にかけての情報技術イニシア ティブの主なものとしては, (1)教育における情報 技術「スウェーデンの学校に情報通信技術を導入 するための国家アクション・プラン」, (2)文化にお ける情報技術「カルチャーネット・スウェーデン」, (3)行政における情報技術「行政の電子化」と「24 時間 $\times 7$ 日の政府サービス」等がある。

2000年3月, 政府は情報技術の急速な発展に対応 するため,「全国民のための情報社会」(IT Bill: “An Information Society for All”) と題する法案において, 将来の情報技術政策案を発表した。スウェーデン の国会は, 2000年6月, 同法案を可決した。

2003年6月, 情報化社会の発展に向けて, 戦略的 なさらなる取り組みの必要性を認識し, IT政策戦 略グループ（IT Political Advisory Group）を選任し た。その後, 2003年12月, 同グループは活動計画 を発表し，任期が終了する2006年11月までの同グ ループの活動, 役割, ビジョン, 目標に関する方 針，重点分野を提示した。

表1にスウェーデン政府における主要情報技術政 策の経緯を示す。

\section{2. 全国民のための情報社会}

スウェーデンは，世界をリードするIT国家とな るべく, 同国の議会は, 法案「全国民のための情 報社会」2)を提案した。その背景には, ITは, 国民 すべてに影響を及ぼし，その生活スタイルにも大 きな影響をもたらすことが考えられる。ITは，現 在, 発展中の新しい社会, すなわち情報社会にお

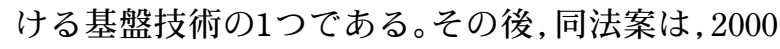
年6月に可決された。

スウェーデン政府は, 基本的に次の $3 つ の$ 政策に 焦点を絞った。

・ITの信頼性一すべての人がIT利用における安 全性を信頼できること

・ IT利用の能力 $-\mathrm{IT}$ の基本的な技術をすべての 人に提供すること

・情報社会のサービスの利用しやすさーITを使っ た情報の検索・利用, コミュニケーション

\subsection{IT政策の基本}

スウェーデンは, 世界をリードするIT国家の $1 \supset$ に挙げられる。政府の積極的な施策によって,こ のポジションにたどりついた。民間部門と国有部 門で大規模にITを利用している。例えば, スウェー デンは無線通信の分野やインターネット利用率で 世界をリードしている。

これらには, いくつかの理由がある。1つは, ス ウェーデンにはこれまでエンジニアリングと改革 の長い歴史があるということ。1998年のパソコン 法案の導入で, 社会の多数のグループが, 技術の 進歩にすばやく対応したという経緯もある。別の 理由は,「知識の向上」という大人向けの教育プロ グラムの実施である。スウェーデンには古くから， 広範囲にわたる電話網が整備されており, 電気通 信市場の自由化（競争への道）が開かれたのは欧 州の中で最も早かった。スウェーデンの大学は他 の欧州諸国よりもずっと前にインターネットへの 接続を開始した。今日多くのスウェーデン人がイ ンターネットにアクセスし, 活発に利用するのは このためである。

スウェーデンの電気通信市場の市場開放は, EU の中で最初の方だった。今日, 約160のビジネス. オペレータが何らかの形で電話事業にかかわって いる。多くのさまざまな企業が競争の激しい市場 で活動し, 電話, 携帯電話, 電話サービスの利用 を大いに促してきた。

そして, 現在, ITや電気通信の発展で最も寄与 している分野は, 携帯電話ネットワークの利用で ある。この分野におけるスウェーデンの研究開発 は，圧倒的に世界のトップクラスにいる。

\section{2. パソコン法}

スウェーデンは, 急速に一家庭あたりのコン ピュータ台数が増加した。この主な理由の1つは, 1998 年1 月に施行されたパソコン法 (Personal 
表 1 スウェーデン政府 主要情報技術政策経緯

\begin{tabular}{|c|c|c|}
\hline 発表時期 & 政 策 & $\begin{array}{ll}\text { 概 要 } \\
\end{array}$ \\
\hline 1994 年 3 月 & 情報技術委員会創設 & $\begin{array}{l}\text { 首相を議長とし，「国民の生活を豊かにし，スウェー } \\
\text { デンの国際競争力を強化するた報技術の利 } \\
\text { 用を促進する」ことを目的。 }\end{array}$ \\
\hline 1994 年 8 月 & $\begin{array}{l}\text { 情報技術委員会「情報技術：人間の } \\
\text { 能力を飛翔させるもの」レポート }\end{array}$ & $\begin{array}{l}\text { 情報社会へ向けたスウェーデンのビジョンを明らか } \\
\text { にし,「教育と研究」,「法制」,「一般行政」,「保健医 } \\
\text { 療」, 「通信ネットワーク」,「商工業」「情報技術リ } \\
\text { サーチ」の } 7 \text { つの領域について提言。 }\end{array}$ \\
\hline 1996 年 3 月 & 情報技術議案提出 & $\begin{array}{l}\text { スウェーデンとしての最初の情報技術戦略を定義。 } \\
\text { 優先課題 } \\
\text { ・法律制度 } \\
\text { •教育 } \\
\text { ・社会全体に対する情報の提供 }\end{array}$ \\
\hline 1996 年 3 月 & $\begin{array}{l}\text { 運輸通信大臣を議長とする第三期情 } \\
\text { 報技術委員会スタート }\end{array}$ & $\begin{array}{l}1996 \text { 年の } 6 \text { 月には, 政府の情報技術議案の結果とし } \\
\text { て, 情報技術委員会に新しい「枠組み」を提起。 }\end{array}$ \\
\hline 1998 年 & 第四期情報技術委員会スタート & $\begin{array}{l}\text { 委員会の議長は産業雇用通信省。任期は } 3 \text { 年から } 5 \\
\text { 年に延長され，より長期的なベースで活動できるよ } \\
\text { うになった。政府とは定期的に協議し，毎年活動レ } \\
\text { ポートを作成する。最終レポートは } 2003 \text { 年 } 5 \text { 月。 }\end{array}$ \\
\hline 1999 年 & $\begin{array}{l}\text { 教育における情報技術 「スウェー } \\
\text { デンの学校に ICT を導入するための } \\
\text { 国家アクション・プラン」 }\end{array}$ & $\begin{array}{l}2001 \text { 年まで続き, 学校の通信インフラストラクチャ } \\
\text { の強化を目的。 } \\
\text { ・政府の助成によって学校のインターネット接続を } \\
\text { より高速にする(特に地方自治体の開発努カを支援 } \\
\text { する)。 } \\
\text { •生徒と教師が全員自分の電子メール・アドレスを } \\
\text { 持つようにする。 } \\
\text { •義務教育と高校の教師 } 60,000 \text { 人（全体の } 40 \% ） を \\
\text { 支援して, 教育スキルの向上に努める。 }\end{array}$ \\
\hline 1998 年 & $\begin{array}{l}\text { 文化における情報技術 } \\
\text { 「カルチャーネット・スウェーデン」 }\end{array}$ & $\begin{array}{l}\text { 実験段階を終了して,「スウェーデン文化に関する全 } \\
\text { 国協議会」が常設の「カルチャーネット・スウェー } \\
\text { デン」を運営。 } \\
\text { カルチャーネット・スウェーデン」は } 1997 \text { 年 }-1999 \\
\text { 年にわたる3か年のプロジェクトとしてスタートし, } \\
\text { スウェーデンの文化資産へのおよそ } 5,000 \text { のリンク } \\
\text { が張ってある。 }\end{array}$ \\
\hline 1999 年 & $\begin{array}{l}\text { 行政における情報技術「行政の電子 } \\
\text { 化」 }\end{array}$ & $\begin{array}{l}\text { 「スウェーデン行政開発庁」の監督のもとに, 各省庁 } \\
\text { は一斉に行政の電子化に乗り出した。 }\end{array}$ \\
\hline 2000 年 1 月 & $\begin{array}{l}\text { 行政における情報技術「24 時間 × } 7 \\
\text { 日の政府サービス」 }\end{array}$ & $\begin{array}{l}\text { 全国民に開かれた「24 時間 } \times 7 \text { 日の政府サービス」 } \\
\text { のプロジェクトをスタート。 }\end{array}$ \\
\hline 2000 年 3 月 & $\begin{array}{l}\text { 情報技術議案「全国民のための情報 } \\
\text { 社会」法案発表 }\end{array}$ & $\begin{array}{l}\text { 政府は情報技術の急速な発展に対応するため, 将来 } \\
\text { の情報技術政策案を発表した。 }\end{array}$ \\
\hline 2000 年 6 月 & $\begin{array}{l}\text { 情報技術議案「全国民のための情報 } \\
\text { 社会」法案可決 }\end{array}$ & $\begin{array}{l}\text { 3つの優先政策, (1)情報技術への信頼を高めるため } \\
\text { の政策, (2)情報技術の能力を高めるための政策, } \\
\text { (3)情報技術へのアクセスを高めるための政策 }\end{array}$ \\
\hline 2003 年 6 月 & 「IT 政策戦略グループ」選任 & 「全国民のための情報社会」の推進。 \\
\hline
\end{tabular}

出典 : スウェーデン政府等発表資料から作成

Computer Reform）である。

パソコン法は, 国民にコンピュータの取得を奨 励するために導入された。この法案の目的は, ス ウェーデンの全国民が, 情報社会がもたらすサー ビスを利用できるようにすることである。

この法律は, コンピュータを購入した企業が, 税金控除を受けられるというもので, 企業が職員
に免税でパソコンを購入し, それを自宅に置くこ とができる。肩書きに関係なく, 長期的な地位に いる人すべてが対象で, 自宅でコンピュータが必 要な従業員だけにとどまらない。この法案によっ て, 小売りよりもかなり低価格でコンピュータが 買えるチャンスが従業員に与えられた。従業員は 通常3年間にわたって給与天引きで代金を支払った。 
法案は成功を収めた。1997年から1998年の間に 自宅でコンピュータを使用する従業員の割合は， $48 \%$ $567 \%$ にがった。したがって, この法案 のおかげで, ITやコンピュータの進展度が上がっ た。また,この法案は, インターネット経由で情 報やサービスにアクセスする可能性を広げている 要因でもある。

\section{3. 主要分野でのITの重要性}

\subsubsection{ITと生活の質}

障害を持つ人の多くは,ITによってコミュニケー ションをとる機会が増える。ITによって, 障害を 持つ人は医療, 教育, 文化, 公開討論, 催しを享 受できる可能性が得られる。このようにして生活 の質が大幅に改善される。

ITによって，障害を持つ高歯者は自宅にいるこ とが容易になる。身内はITを使って介護の必要性 やサポート手段に関する支援, 知識および情報を 得られる。また, ITによる自宅での最新式へルス ケアなど健康管理の向上によって安全性がもたら される。

\subsubsection{ITと民主主義}

インターネットの発展によって, 直接民主主義 への道が開かれ，国民にとって公的機関の透明度 が増し, コントロールや意見交換がしやすくなる。 ITは国民がさまざまな問題についてコミュニケー ションをとり, グループを作るための新しい道を 開く。

ほとんどの政府機関, 地方自治体, 県議会は, 各 自Webサイトを持っている。個人や企業は組織や 政治家と接触する機会が与えられている。民主主 義や意見交換，そして政治への影響力を強化する 1つの方法は, 地方自治体や県議会のWebサイトで 多くの政治家を紹介することである。一般的に, 彼らは電話番号と同様に電子メールアドレスを持っ ており,これによって誰もが政治家に電子メール を書くことができる。

これらのWebサイトの中には, 国民と一緒に電 子会議を開くためのフォーラムがある。国民はお 互いに,または選出された代表者と意見交換できる。

このような電子フォーラムは, 特定の地方自治 体や県議会で展開されている。今後, 国民や組織, 政党, 大衆運動, 研究機関でさまざまなネットワー クが構築され, 電子フォーラムを使って運営され る可能性がある。

\subsubsection{ITとマスメディア}

マスメディアは，現代の民主主義の中で非常に
重要な存在である。マスメディアは, 自分たちの 持っている知識を一般市民に提供し, 共に生活し 活動できるようにしてくれる。

IT, 主にインターネットのおかげで, 情報を発 信したりアクセスしたりする機会が大幅に増えた。 したがって，マスメディアの状況も変化した。異 なる種類のメディア間における境界線があいまい になり，メディア同士でオーバーラップする部分 が出てきた。例えば, 従来のメディアの中で流通 経路に進出しているものもある。メディアとコン ピュータ通信との間の境界線もはっきりしなくなっ ている。

インターネット自体は, 情報にアクセスする1つ の方法になっているが, 新聞もインターネット上 で読むことができる。文字テレビも $1 つ$ 例であ る。これはテレビで文字による情報を読めるよう にしたものである。もちろん, 携帯電話であらゆ る情報にアクセスすることもできる。

これらのことは,IT構造の発展が将来マスメディ アにとって重要になることを意味している。

スウェーデン政府は, IT政策に取り組むことに よって, マスメディアが民主主義の重要な機能を 継続して果たすことができるように願っている。 例えば, ITの発展に関連した政治判断が表現の自 由, アクセス性, 多様性, 選択の自由の点で目的 に基づいていなければならない。

つまり，マスメディアが一般市民と接触し，市 民が欲しいと思う情報を提供するにあたって，妨 げがあってはならない。

また, 法制化も影響を受ける。ITが発展した結 果, 情報がどのように配布され, その情報がどの ような形式で受信者に届いているかによって, い くつもの異なった法律にかかわってくるマスメディ アもある。これらの法の中には, 表現の自由, ラ ジオやテレビ, 電気通信事業に関する基本法が含 まれている。

\section{4. 新しい/T政策}

1996年に作成されたIT政策は, ITの発展が極端 に速いため作り直す必要が生じた。現在ではITの 利用方法に関してまったく新しい可能性が出てき ている。国際競争の激化もIT政策を作り直すため のもう1つの理由である。スウェーデンは世界を リードするIT国家としての地位を維持するために IT政策を再検討する必要があった。

初期のアプローチは1996年から続いている。IT の利用率は，できるだけ多くの人がITを認識する 
ことによって向上する。ITの認識は, 創造性, 成 長, 雇用にもつながる。また, IT政策はスウェー デンの競争力向上, 知識・民主主義・正当性の向 上, 男女の平等, 福祉国家の発展, 行政における 効率性の向上をもたらす。

しかし, 以下の理由で初期のアプローチを変更 する必要があった。

・数多くのコンピュータや携帯電話を環境に無 害なサイクルで処理する必要がある。また, 環 境に優しい輸送や環境モニタリングなどによっ てITが環境改善に貢献することは重要である。 ・新しい技術インフラの開発が市場によっての み管理される場合，国内の人口過少地域に住 む人々は利用できないというリスクがある。政 府の仕事は,すべての国民がITネットワークに アクセスできるようにすることである。

・IT政策は，民族の多様性や統合の問題を考慮 する必要がある。IT政策はグループごとにITに アクセスできる範囲を決定できる。

IT政策が策定されるときに, 優先事項を明確に 決めることが重要であった。ITへの信頼およびIT のセキュリティは非常に重要な問題である。例え ば, 電子商取引はセキュリティに非常に依存して いる。ユーザはセキュリテイ技術や新しい法律を 信頼しなければならないため, 他の法案によって 電子商取引を円滑に進める必要がある。

教育に関しては，そのコンセプトはITサービス を利用する際の人々の能力を含めて拡大されてい る。能力は学校や職場での教育またはITの実践教 育によって身に付けられる。

パソコン法案によって, 家庭でコンピュータを 持つ人が増えた。これは, 一般の人々の能力向上 の礎となった。これらの法案に加えて, スウェー デンはIT国家のリーダであり続けるため，またそ れにより, 国際市場での優位性を保つために,さ らに多くのIT専門家の訓練または確保が必要だった。

\subsection{IT分野における優先事項}

スウェーデンが「全国民のための情報社会」に なるという目標を達成するために，IT政策は主に 規制システム，教育，トレーニング，インフラに

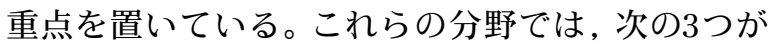
優先される。

・ITの信頼性

・ IT利用の能力

・情報社会のサービスの利用しやすさ

スウェーデンが他のIT国家と足並みをそろえる
場合は, 労働力への高度かつ特別な要求, 資本調 達, コンピュータの認識等に必要な条件をそろえ なければならない。

すべての人は, ITを使った通信, 商取引, 生活 の質の向上に信頼を寄せることが大事である。す べての人は, IT利用の基本知識を持つべきである。 国内および国外のITシステムへのアクセスは，国 内全域で可能である。これらの方策はできるだけ 早く施行されるべきであると述べている。

\section{3. 情報通信技術クラスター}

スウェーデン政府は, 国際競争力を保持した情 報通信技術を進展させるために，スウェーデンの 主要な地域で「情報通信技術クラスター」を推進 している3)。

スウェーデンの情報通信技術クラスターは, 外 国企業から非常にアクセスしやすい存在でもある。 企業間協力やさまざまなネットワーク活動への開 放性は, 外国企業の参入や優れたイノベーション を促進している。

スウェーデンには, いくつかの国際的に競争力 のある情報通信技術クラスターがある。主なクラ スターとしては, モバイルバレー, テレマティク スバレー, テレコムシティ, ホームコム, インター ネットベイ等が挙げられる。有名な大学や研究所 が近接していること, また十分な数と規模の企業 があることが，これらの共通項となっている。相 互関連企業, 専門サプライヤ, 学術研究所, 工業 研究所, サイエンスパーク, テクノロジーインキュ ベータ, ベンチャーキャピタル会社などのネット ワークによって, これらのクラスターはイノベー ションを生み出すュニークな存在となっている。

\section{1. テレマティックスバレー}

イェーテボリのテレマティックスバレーは, 車 載情報システムの世界第一級のセンターとして急 速に発展した。このクラスターの発展の理由とし て, 各種産業部門, 公共研究活動が統合的にそろっ ていることが挙げられる。世界的な2つの自動車 メーカ (VolvoとSaab) , および世界最大のトラック メーカの1つ（Volvo Trucks）が，ここに本部を置 いている。同様に, 移動体通信および無線技術を リードするストックホルム/キスタ・クラスター の発展には, エリクソン（Ericsson）が大きな役割 を果たした。 


\section{2. クラスター発展に対する支援}

クラスターの発展と向上は, スウェーデン政府 および地方自治体にとっての優先事項である。例 えば，スウェーデンのイノベーションシステムを 支援・促進するための，国家資金による機関 VINNOVA（Swedish Agency for Innovation Systems : スウェーデン技術開発庁) ${ }^{4)}$ の設立が挙げられる。

VINNOVAは, 効果的なイノベーション・システ ムを開発し, 資金を供給することにより, 技術, 交 通，ワーキング・ライフ等を支援する産業省所属 の政府機関である。

2001年に, 旧NUTEK（Swedish National Board for Industrial and Technical Development)が再編され,以 下の3機関となった。公的機関の充実したサービス によって, 起業家の成長が助けられている。

- NUTEK (Swedish Business Development Agency）: 起業家支援, 地域開発, ファイナン ス, 調査・分析の 4 つの機能を持つ機関

- VINNOVA (Swedish Agency for Innovation Systems）：研究・技術開発に投資し，持続的開 発に資するイノベーションを誘引する機関

•ITPS (Institute for Growth Studies)：経済成長に 資する, 統計データを収集・分析する機関

VINNOVAの主要な目的は, イノベーションの開 発に必要な支援をすることによってスウェーデン の経済の成長させることである。産業雇用通信省 の所管にある組織であり，産業政策・研究開発の 観点から設立されているため, 教育・研究を所管 する文部省とも連携を持っている。産業雇用通信 省の組織5)を以下に示す(図1)。

VINNNOVAの職員は，全体で約150名である。最 高決定機関である, 理事会は研究分野, 産業界, 公 共分野からの代表者で構成され，同機関の事業展 開等を審議する。

\section{3. 移動体テストベッド}

新移動体サービスを試験および評価するための プロジェクトが，スウェーデンの全地域で確立さ れている。大学, 市議会, 業界が共同して, 無線 技術から国民がどのように利益を受けようとする かを調べている。

a. Eストリート

ルーレオのEストリートプロジェクトは, ポジ ショニングの評価を行った。ポジショニングシス テムを使用し，近傍エリアの顧客にメッセージを 送って, 地域のビジネスマンは, 適切な顧客を探 す。2000年から実施されているこのプロジェクト
は,ルーレオ大学, Ericsson, Teracom, Frontec, Telia による共同事業である。

b. mCity

ストックホルムの市議会は, 公共携帯サービス を提供する 2 年間のパイロットプロジェクトであ る, mCityをスタートさせた。このプロジェクトは, Maria-Gamla Stan地区を対象にした。

c. Wireless Peopleプロジェクト

カールスクローナ／ロネビー・クラスターの Wireless Peopleテストベッドは, 2003年1月に開始 された。12のサービスが計画され，学生，ビジネ ス，市民を対象としている。

\section{4. デジタル・ゲーム産業開発}

\section{1. ゲーム産業の発展}

この 20 年間で, スウェーデンのデジタル・ゲー 厶開発は, 個人の趣味の世界からからべンチャー 投資家の対象へと飛躍し, 数百万ドルの産業へと 発展しつつある6)。

1980年代後半, PCがスウェーデンの家庭にも進 出し, 熱心なプログラマーの小集団が，のちに発 展した個人によるゲーム開発産業の基礎を築いた。 1990年代になると,この開発コミュニティは世界 のゲーム市場に合わせて，劇的な成長を見せた。

しかし，開発はいまだ小さなスタジオで，結束 力の緩いネットワーク内で行われていたが, 今や スウェーデンは, 米国, 英国, 日本と並んで, コ ンピュータゲームの純輸出国たる数少ない国の $1 つ$ である。

\section{2. ゲーム産業のヒットの理由}

スウェーデンのゲーム産業のヒットの理由は, いくつか考えられるが, 以下のようなものが挙げ られる。

(1) PC, インターネット,ブロードバンド, 携帯電 話の高い普及率

(2) デジタルサービスの先進的ユーザ

(3) 大規模で構造化されたゲーム開発産業

(4) ゲーム開発技術・方法論における, 教育と研究 の確立

(5) メディアおよびエンタテイメント技術の, 第一 級の作製者

(6) 新技術を開発, テストし, 立ち上げるためのリ ソースの卓越した組み合わせ

(7) 世界最大の無線技術クラスター 技術の創造的な使用と独創的なゲーミングアイ 


\begin{tabular}{|l|}
\hline 産業貿易大臣 \\
Minister for Industry and \\
Trade \\
副大臣 \\
State Secretaries \\
\end{tabular}

男女共同参画政策調整 担当大臣*

\begin{tabular}{|l|}
\hline 通信地域政策大臣 \\
Minister for \\
Communications and \\
Regional Policy \\
副大臣 \\
State Secretary
\end{tabular}

雇用大臣
Minister for Employment
副大臣
State Secretary

革新システム庁および 付随問題担当教育科学

大臣**

* Minister responsible for coordination of the gender equality policy

** Minister for Education and Science responsible for the Swedish Agency

for Innovation Systems (VINNOVA) and appurtenant issues

\section{法務局}

Legal Secretariat

\section{研究分析事務局}

Secretariat for Research and Analysis

\section{行政サービス局}

Secretariat for

Administrative Services

\section{情報広報事務局}

Secretariat for Information and Public Relations

\section{調整局}

Coordination Secretariat

\section{欧洲国際調整局}

Secretariat for European and International

Coordination

図 1 産業雇用通信省 組織 出典 : スウェーデン産業雇用通信省発表資料より作成
デアは, 優れたゲームを製作するための 2 大要素で ある。他の業界や研究機関からの技術を利用でき ることは, スウェーデンのトレードマークとなっ ている。また, スウェーデンのゲーム開発者は, 再 使用可能コードの豊富なライブラリを構築してい る。その多くがパッケージ化されたプラットフォー ムと, 他の開発者にもライセンスできる手段を備 えている。オンライン／携帯ゲームを含む高度な ゲーミングソリューションのために, $3 \mathrm{G}$ エンジン やレンダリングッールなどのプラットフォームを 利用できる。

\section{3. ゲーム産業の開発地域}

スウェーデンのゲーム産業は, ストックホルム /ウプサラ地域をはじめ, ウメア/ルレア地域, リンコピング地域等, 全国に5地域ほどである。そ れぞれの地域の特色を生かしながら開発や製造を
行っている。これらの地域は, 前述の情報通信技 術クラスター地域とほぼ同じ地域に位置している。 これは, 情報通信技術クラスターとの連携を意味 している。

例えば, ストックホルム/ウプサラ地域では, 27の企業, 226の開発者, ウメア/ルレア地域では, 10の企業, 30の開発者が活動している。さらに, そ れぞれの地域には, ハイテク研究機関が技術面か らのサポートを行っている。例えば, ストックホ ルム/ウプサラ地域では, Royal Institute of Technology, SICS (Swedish Institute of Computer Science）等が先端技術をサポートしている。

\section{IT政策戦略グループ}

スウェーデン政府は, 2003年6月, IT政策戦略グ ループ7)を設置した。このグループは, 政府の諮問 
機関としての役割のほかに,「全国民のための情報 社会」というIT政策目標達成への取り組みのなか で積極的役割を果たすこととした。もう1つの中心 的課題は, IT発展の最前線におけるスウェーデン の主導的地位を維持するため, 他国との協力を推 し進めることである。

戦略グループは, 特に次のような課題に取り組 んでいる。

・技術革新を促進するための環境整備

・競争や技術の面で中立的な統合的電気通信ネッ トワークを積極的に推進

・ブロードバンド・ネットワークの拡大推進で 政府が役割を果たすべき分野を特定

・ITへの一般市民の信頼を高めるため，役割を 果たすべき分野を特定

・情報社会の社会的，文化的影響に関連して発 生するリスクと機会を評価

・将来, IT政策や情報社会のコンセプトをどの ように発展させることができるかについて提案

\section{6. おわりに}

本稿では, 最近のスウェーデンのIT政策につい て概観した。スウェーデン政府の包括的なIT政策 は，1994年3月，情報技術委員会が設置され，「国 民の生活を豊かにし，スウェーデンの国際競争力 を強化するために，ITの利用を促進する」ことを 目的とした。さらに，1994年8月，同委員会は，「情 報技術：人間の能力を飛翔させるもの」と題する レポートをまとめた。このレポートは，情報社会 へ向けたスウェーデンのビジョンを明らかにし， 「教育と研究」,「法制」,「一般行政」,「保健医療」, 「通信ネットワーク」，「商工業」「情報技術リサー チ」の7つの領域について提言している。他の国々 と比較すると情報社会への取り組みは, かなり早 かったと言われている。

その後, 法案「全国民のための情報社会」を提 案した。その背景には，ITは，国民すべてに影響 を及ぼし，その生活スタイルにも大きな影響をも たらすことが考えられる。ITは，現在，発展中の
新しい社会，すなわち情報社会における基盤技術 の1つである。その後, 同法案は, 2000年6月に可 決された。これにより, 情報社会へ向けた活動計 画が確立された。

スウェーデンが, 今日, 世界でもトップクラス の情報社会の先進国となった理由は，いくつか考 えられるが，まず，第一に挙げられるのは，その 地理的要因ではないだろうか。スウェーデンは国 土の 3 分の 1 扎極圈で, 国土は日本の 1.2 倍あるが

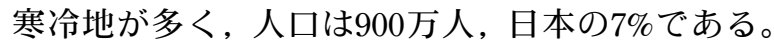
過酷とも言える気象条件で, 長くて寒く, しかも 暗い冬は，人々や町を外界から孤立させ，外出や 移動時に, 携帯電話を持つことは, 生命の安全を 確保するためにも必要なことである。かくて, 携 帯電話やインターネットは早期から必須となった。 また, 道路網の遅れが, 代替手段としての通信の 発達を促したということもある。

次に考えられるのは，社会経済的要因である。 資源がそれほど豊富でない小国が, 高い生産性と 生活水準を維持するためには, 貿易に依存せざる を得なかった。また，全国民を対象とする教育を 高いレベルに維持することにも積極的であり，低 学年から英語を教えほとんどの国民が英語を話せ ることでインターネットにも入りやすかったと言 える。また, スウェーデン政府が, ITに早期から 積極的に取り組んできたことも大きな影響を与え ている。通信市場の自由化, 通信コストの低下, 通 信インフラ整備, さらに, 国際的競争力を持った 情報通信技術クラスターの推進も大きな要因と考 えられている。情報通信技術クラスターは，外国 企業から非常にアクセスしやすい存在である。企 業間協力やさまざまなネットワーク活動への開放 性は, 外国企業の参入や優れたイノベーションを 促進している。

スウェーデンを含む北欧の国々は, 情報社会の トップランナーといわれている。国土をはじめ日 本と似ているところもある。日本のIT進展度もこ こ数年, かなりのレベルにまで達してきているが, これらの国々の状況は，日本のIT政策にとって参 考になるものと思われる。 


\section{参考文献}

1) World Economic Forum. "Global Information Technology Report 2004-2005 The Networked Readiness Index Rankings 2004”. (online), available from < http://www.weforum.org/pdf/Global_ Competitiveness_Reports/Reports/GITR_2004_2005/ Networked_Readiness_Index_Rankings.pdf $>$, (accessed 2005-09-05).

2) Ministry of Industry, Employment and Communications. "An information society for all - a publication about the Swedish IT-policy". (online), available from <http://www.naring.regeringen.se/ pressinfo/infomaterial/pdf/n2000_57.pdf $>$, (accessed 2002-08-06).

3) Invest in Sweden Agency. "ICT - information \& comm. technologies”. (online), available from <http:// www.isa.se/upload/Filer/pdf/ISA_ICT.pdf $>$, (accessed
2004-05-20).

4) VINNOVA. "VINNOVA SE". (online), available from $<$ http://www.vinnova.se/>, (accessed 2005-09-05).

5) Ministry of Industry, Employment and Communication. "Ministry of Industry, Employment and Communication Sweden". (online), available from <http://www.sweden.gov.se/content/1/c6/01/84/56/ b1edd976.pdf $>$, (accessed 2005-09-05).

6) Invest in Sweden Agency. "Game Development”. (online), available from < http://www.isa.se/upload/ Filer/pdf/ISA_GameDevelopment.pdf $>$, (accessed 2004-06-11).

7) Government Offices of Sweden. "IT Policy Strategy Group”. (online), available from < http:// www.sweden.gov.se/sb/d/2156/a/22411>, (accessed 2005-09-05). 